\title{
Krzysztof Kieślowski's Art of Film
}

\author{
By Tadeusz Miczka \\ Spring 1997 Issue of KINEMA
}

\section{"WE LIVE IN THE WORLD LACKING IDEA ON ITSELF: KRZYSZTOF KIEŚLOWSKI'S ART OF FILM"}

OUR "little stabilization" -- this ironic phrase by Tadeusz Różewicz, the poet and playwright, rightly characterized the low living standards of Poles and the state of apathy of the society in the 1960s. It also reflected well the situation of the Polish culture which, at that time, was put under strong political pressure and, except for very few instances, half- truths and newspeak replaced the clear dichotomy of truth and falsity. However, it finds its strongest expression if seen against the background of the Polish cinema of that time, since the cinema was, so to say, the "light in the eyes" of the Workers' Party activists devoutly building the 'real socialism' state.

After the period of the political thaw which, among other things, brought to life artistically courageous works of the 'Polish film school', the political authorities again demanded to be the only power shaping people's opinions and their style of life in the country. The film art could meet viewers' needs only to a very small extent. Its major task however, was to shape those needs and that is why cinema was part of the mechanism used for indoctrinating the society. Very few film directors were able to liberate themselves from the rigid ideological rules and fight the censorship efficiently.

Through different means, some of them succeeded, e.g. Andrzej Wajda (Popioty - Ashes, 1965 and Wszystko

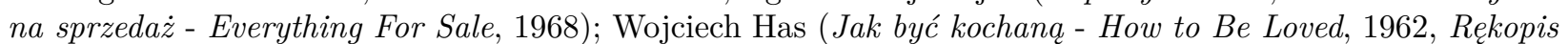
znaleziony w Saragossie - Manuscript Found in Saragossa, 1964, Szyfry - Codes, 1966 and Lalka - The Doll, 1968); Jerzy Kawalerowicz (Matka Joanna od Aniolów - Mother Joan of Angels, 1961 and Faraon - Pharaoh, 1966); Tadeusz Konwicki (Zaduszki - Halloween, 1961 and Salto - The Somersault, 1965), as well some other filmmakers. Gifted young directors such as Roman Polański (Nóż w wodzie - Knife in the Water, 1961) and Jerzy Skolimowski (Rysopis - Identification Marks: None, Walkower - Walkover, 1965, Bariera - Barrier, 1966 and Ręce do góry - Hands Up, 1967 - released in 1985) decided to leave the country.

Artistic ambitions were frustrated and surrogate subjects dominated the film production. Mostly unattractive and tendentious movies were produced. ${ }^{(1)}$ The feature film cinema was revitalised after 1968 when politicians started competing for positions inside the party and the extent of the poor living conditions became evident. The established directors started making movies again: Wajda for example realized film adaptations of literary works by J. Głowacki (Polowanie na muchy - Hunting the Flies, 1969), J. Iwaszkiewicz (Brzezina - Birch Wood, 1970) and T. Borowski (Krajobraz po bitwie - Landscape After the Battle, 1970). However the real breakthrough was achieved by representatives of the 'young culture' movement who spoke openly on everyday matters, such as Krzysztof Zanussi in his film Struktura krysztatu (Structure of Crystals, 1969). They also showed the postures and slogans of the official culture as in a broken mirror, such as Marek Piwowski in Rejs (Cruise, 1970).

In the 1960s the same political reasons caused stagnation in the documentary cinema. Probably the only interesting phenomena was the so-called "sociological trend." This was created by Krzysztof Karabasz with the help of a small group of cin,ma-v,rit, fans. Karabasz (Muzykanci - The Band and Ludzie w drodze People on the Road, 1960; Rok Franka W. - Franek W.'s Year, 1967), a professor in the Film School in Lodz, greatly influenced his students who mastered the skill of habituating the common people to the presence of the camera. In the middle of the decade only their documentaries had the power to reveal the naked truth of the Polish reality; soon they became an important source of inspiration for other young artists.

Krzysztof Kieślowski (1941-1996) was one of Karabasz's students, and his student films (Tramwaj - The Tram, Urzad - The Office, Koncert życzen - Concert of Requests, Zdjęcie - The Photograph and Z miasta Lodzi - From the City of Lodz, 1966-1969) reflected his admiration for his teacher. Kieślowski followed the path pointed by Karabasz for a long period of time. When making his early pictures, Kieślowski strictly followed the rule of concise presentation of an event which enabled the director to get closer to the essence 
of the subject. However, he also expressed his own attitude towards the reality and art, since making films for him was not only recording the world but interpreting it as well.

Kieślowski did not try to hide his skepticism as far as depiction of the world was concerned. He expressed this strongly in The Picture. In this documentary Kieślowski himself acted as a director searching for a smiling boy from a photograph taken just after Warsaw had been liberated from Nazi occupation (this, by the way, was the only time he acted one in his movies). When the young boy was finally found, it turned out that looking at the picture made him sad. Nobody knew that the first day of freedom was also the day when his mother died; he did not know about it when the photograph was taken. This film already managed to show much of the scepticism Kieślowski felt towards reality as presented on the photograph or on the screen. The events surrounding this film confirmed his opinion that between the truth of the film and the truth of the character's inner experience, there exist barriers that cannot be crossed.

Another aspect of Kieślowski's artistic creed and personality was exhibited in his short film on Lodz: In it one can see buildings falling apart shown against the background of optimistic comments. Here the director used irony and from that moment on it became one of the main trademarks of his style. This sort of subjective opinion was in the late 1960s a unique attitude in the Polish documentary cinema.

K. Kieślowski: ...I thought that graduating from the film school would make me know something about the theatre and directing... It wasn't any goal in itself, the film school was only a certain stage I could then use for something. So I went to this school, I mean I tried to get there... and I didn't succeed, by the way. K. Wierzbicki: How many times did you try?

K. K.: Three.

K. W.: But the last time you stubbornly decided to succeed?

K. K.: The last time I stuck to this. Yes, I thought, 'You, bastards, you don't want me, so you'll have me there!'

K. W.: And you graduated from the school and soon you started making those sad, black and white movies.

K. K.: You know, the whole world around was very sad, it was not even black and white, it was just black, or maybe gray. This is directly connected with a certain place where the school was and still is, I mean with Lodz. Lodz is... photogenic because it is dirty and crappy... The whole city is like that, in a certain way, the whole world is like that. And people's faces are like city walls: sad, full of a drama in their eyes, you know, the drama of pointless life where you make steps for nothing... I think we were the first after the war [...] who tried to describe the world as it was. Of course, those were tiny worlds, in fact worlds in a drop of water, and even names were like that: the primary school, or the factory, or the hospital, or the office. We described those tiny worlds as we hoped they were put together somewhere into something bigger. We hoped to describe life in Poland.

K. W.: But why should such worlds be described?

K. K.: It's hard to live in a world lacking description. It cannot be understood if one didn't live in a not-described world. It is as if you lived without identity. Simply, anything around [...] has no reflection, anywhere. You can't see any reference point around, for nothing has been described and nothing has a name. So you live on your own, alone; anything that could be used to describe the world was used by propaganda to build the theoretically attractive idea, but... in reality, unfortunately, it always ends up the same way: I mean, you feel a gun on your head. We lived by ideas of fraternity, equality and justice, but there was neither fraternity, nor equality and no justice at all. ${ }^{(2)}$

Between 1970 and 1971 -- along with Tomasz Zygadło, Krzysztof Wojciechowski, Andrzej Titkow, Marek Piwowski and Grzegorz Królikiewicz -- Kieślowski became one of the leading representatives of the new wave in Polish documentary cinema. He belonged to the youngest generation of artists who believed that film could establish an effective means of social communication but only when it had the shape of a journalistic genre free of explicitly expressed opinions. This was a difficult task since it is hard to be an objective observer in a country where political authorities have power over everything, where political opposition is suppressed and the society does not have an easy access to the objective information. That is why Kieślowski's early films, dedicated to the general audience, were strongly imbued with ambivalence. 
In Byłem żotnierzem (I was a Soldier, 1970) the artist discussed the idea of an effortless victory, popular in the Polish cinema and official propaganda; the character of the film, a veteran of the World War II, was shown as an ordinary blind man condemned to the help of his community. This heroic confrontation with the power destroying one's dreams and hopes reveals the complexity of human life. In Fabryka (The Factory, 1970) Kieślowski contrasted two perspectives: one was a report from a tempestuous convention of the tractor factory's management, while the other showed the labourers' harsh working conditions. It was difficult for the viewers to see the importance of the problems discussed by the management, with the chief manager ineffectively trying to fight off ridiculous laws. These events along with portrayals of surly workers produced a sorry image of the socialist company.

Pessimistic conclusions also dominated Kieślowski's document concerning sport. The film Przed rajdem (Before the Rally 1971) reported the preparations of the Polish car driver for the Monte Carlo race. Sport topics gave the director an opportunity to discuss the difficulties and problems preventing people from carrying out the most common tasks. However, it was only when he made Refren (Refrain, 1972) that the viewers could see the brilliant depth of his ironical attitude toward Polish reality. In fact, the positivesounding title was given to the picture showing bureaucracy's supreme reign at the mortuary.

Looking at the Polish everyday life in the 1970s, Kieślowski avoided great and pretentious phrases, wellknown personalities and national myths. He simply showed what was important for common people as well as for himself. Critics and audience appreciated his early films because their veracity and because they reflected the director's concerns as a man without pretending to be an artist, creator, moralizer or teacher. He gave viewers opportunities to ask themselves: How should I live? (only one of his characters asked this question explicitly) and he never tried to make obvious conclusions. He returned to the question in Prześwietlenie (X-ray, 1974), a psychological portrayal of patients suffering from tuberculosis. The film was based upon observations made by the director during meetings with his dying father in a hospital.

K. Kieślowski: "What do I wish? Calm. But this cannot be given. Nevertheless, we can seek this. The way you seek is stimulating. [...] When I was making films I often wished not to finish them. [...] In every single movie I -- honestly speaking -- direct the camera at myself. Not all the time, only when no one can notice it. [...] I've got one pretty good virtue which is my pessimism. That's why anything I can see is black. Really anything. The future for instance is for me you know, like a black hole. If I am ever afraid of anything I am afraid of the future... The place I am in is a bit better than the one I should be in. I was given a better place to live, you know, I sit in a better row than I really deserve."(3)

However, Kieślowski's documentaries rarely managed to reach a wide range of viewers since politicians and censors did not like their conclusions. The story of the former political activist creating (or 'building' -- as was the fashionable term of the period) socialistic state and the 1956 events (militia's attack on protesters and subsequent political changes at the top levels of the Communist Party) differed so much from the official versions that the Murarz (Bricklayer, 1973) shot during the 'velvety' period of Edward Gierek's administration was released only in 1981, when the Independent Trade Union "Solidarity" movement was already active.

The film Robotnicy '71: Nic o nas bez nas (Workers '71.: nothing about us without us, 1972), was treated even worse. The production was actually ordered by the officials of the new political administration. Contrary to the authorities' expectations, the film which was supposed to demonstrate "workers' concern for the future of the country" and "public support for the party's activity" was not brought to life. Instead, Kieślowski and Zygadło did nothing but record pure events; this way they managed to show an activist falsifying scores after the elections for Workers' Council as well as the workers revolting against the electoral deception in their factory. Despite the director's objections, the film was re-edited and its 'proper' ideological version, entitled Gospodarze (Managing Masses) was shown on television.

Kieślowski was a man of integrity and did not intend to give up his artistic control, although his attitude caused several skirmishes with the authorities. After this, he decided to avoid difficulties and find distributors for his films. He offered the state producer his help in the production of training films for use at party's instructional courses. Probably only the picture entitled Podstawy BHP w kopalni miedzi (The Principles of Safety and Hygiene in a Copper Mine, 1972) served the former idea; however, Życiorys (Curriculum vitae, 
1975) produced for closed party circles already was "a dreadful record of breakdown of morality, but also evidence of preserving his dignity." ${ }^{(4)}$

The film is based on a report from the conference of the Provincial Committee for Party Control discussing an appeal of a worker expelled from the Communist Party. Among other things he was charged with getting married in church and baptizing his child. This exposed the ideological mechanisms as well as the immoral nature of the 'leading party's role' in fighting off non-conformist attitudes. Curriculum Vitae was written for the 'condemned' by the director, while the lines from the script were performed by real activists, but the audience did not know about this. The film was awarded a prize at the Cracow Film Festival and became a legend, while in 1976 it was awarded with "Yeast" prize -- the Polish weekly's "Polityka" award for its propagation of open-mindedness and clear thinking.

The documentary subverting the authorities' intention caused confusion in political circles. However, the government gave up working with Kieślowski but not before the closed-door presentation of Nie wiem (I Don't Know, 1977). This was the interview with the manager of an iron works who was dismissed for supposed mistreatment of his subordinates. The character painted a very dark vision of the existing social relations and economy in Poland and finally said: "I've lost everything I've reached in my life. I must state I don't know how to live" -- this caused the film to be premiered immediately after the rise of "Solidarity." Undoubtedly the young documentary director tried to convince the viewers that the Polish United Workers' Party ${ }^{(5)}$ was to be regarded neither as the legal authority in Poland nor the worker's representative.

The director also criticized party activists in his films Pierwsza mitość (First Love, 1974) and Szpital (Hospital, 1976). In the former picture, a young couple expecting a child and wishing to get married are forced by different institutions and offices to go through countless difficulties. The latter documentary depicts 24 hours inside a casualty orthopedic surgery in one of the Warsaw hospitals showing the selflessness of the staff in destitute conditions. The film accused the government and the people who claimed the necessity of accepting the existing conditions, of hypocrisy. This production was awarded the Grand Prix at the International Film Festival in Cracow.

K. Wierzbicki: "Why was there so much politics in your pictures?" K. Kieślowski: "Because politics was and still is around us. And in those days [...] I thought it had a significant meaning. I thought politics could really help anything and first of all that politics was up to us. It was directly connected with hopes [...] that everything would be better, that any reforms would be possible or that everything would be pushed the right way. Nobody could even dream that communism would fall by itself, nobody thought this way. Rather than that we wished that life would be a bit easier and we would have at least a grain of freedom. [...] People watched the screen and felt we told their story. I think it was a notable feature of the 1970s' movies, I mean that people saw themselves on the screen." K. W.: "But probably they finally felt together. They staged a couple of revolts. [...] And the latter revolt brought what we had all dreamt about." K. K.: "Well, it only brought shit and we achieved everything, but for me it turns out that what we achieved satirized what we had dreamt about."(6)

In the middle of the 1970s when economic prosperity peaked in Poland, Kieślowski reconsidered why there was so much stupidity and evil in everyday reality. He realized that although ideology influenced human behaviour in the highest degree, there were also other circumstances -- sometimes man-made and sometimes completely coincidental -- shaping his nature. In his press interviews the director often spoke about moral dilemmas which accompany film making and about the necessity of recording the reality from a detached point of view.

After 1976, when Kieślowski had already produced a documentary Krotki dzien pracy (Short Working Day) and his first feature film Blizna (Scar -- two of his worst pictures ever made, as he claimed), the director gave up non-fiction film making.

The character of a documentary originally entitled Widok z okna (View From a Window) was a party secretary in a provincial town who confronted a crowd protesting in front of the committee office, calling for immediate improvement of living conditions. Kieślowski used a popular archetype here: A lonely individual versus a hostile crowd -- and turned it upside down. First he seemed to side with the man fighting for ideological 
principles, but then the filmmaker changed his point of view and denounced the secretary's action as the product of the political system. The film was banned. However, in 1989, when distributors wished to release it, the director refused as he thought his work to be unworthy, unnecessary and morally ambiguous.

In Scar (which often contained documentary elements) Kieślowski brought back the character of a factory manager facing a moral dilemma. In this conflict which pitted town residents and workers against the man trying to represent the government with dignity, the filmmaker's opinion was quite vague. He explained it later to journalists that participating in the cultural life of socialist Poland meant complying with certain rules there. Nevertheless, it is hard to appreciate this work as a successful one. However, in trying to show that the truth escapes the camera, he joined the philosophical approach in world cinema pioneered by Michelangelo Antonioni. Watching Scar we can agree with the Italian director that there is a hidden reality behind every image and this is why nobody can ever capture an absolute image of the world. This point of view was further developed by Kieślowski in his forthcoming feature films.

The artistically unsatisfactory movies mentioned above followed two earlier and successful TV feature productions Przejście podziemne (Pedestrian Subway, 1973) and Personel (Personnel, 1975) and, against the expectations of critics, Kieślowski decided to change to feature film making. He stated that presenting fictional stories would enable him to observe human psychological and sociological implications from a wider perspective. But it took him a long time to abandon the documentary production, in which he excelled and had made him famous in Poland as well as abroad.

For example, the viewers were deeply touched by the interview with an old doorman $Z$ punktu widzenia nocnego portiera (From a Night Porter's Point of View, 1977) who was a fanatic about maintaining discipline both at work and beyond. The man controlled the private lives of his colleagues through his view that regulations were "always more important than any man." Kieślowski's film about dancers from a classical ballet group Siedem kobiet w różnym wieku (Seven Women of Different Ages, 1978) was also much appreciated; those women had to share their lives between numerous duties and were unable to concentrate on their profession. A journalistic style was employed also in his documentary Dworzec (Station, 1980), a report on the Warsaw Central railway station at the time of the evening TV news. The two worlds, one of propaganda and the other of reality, differed from each other in all respects.

The last of Kieślowski's non-fiction films proved that his uncompromising position against the falsified and ideologized reality was mellowing. Gadajace głowy (Talking Heads, 1980) was a passionless record of a public survey. People of different ages and professions answered questions about their identity, dreams and expectations. The film renounced any artistic effects and foregone conclusions; at the same time it refused in any way to manipulate people's statements. In this way it brought out painful existential experiences of the modern society. Later, Siedem dni w tygodniu (Seven Days a Week, 1988) was made by the artist as a part of an international series (produced by City Life, Rotterdam) which presented cities through the eyes of famous filmmakers. Kieślowski portrayed Warsaw.

K. Kieślowski: "[...] I made films to talk to people. Of course, any conversation involves a certain kind of responsibility on the part of the interlocutors. But let's not blow this up. It's still only conversation, exchanging ideas or impressions or emotions. The result is either getting a man wiser or dumber. And that's the whole responsibility. Nothing more. I at least cannot point any better. I know, some people are convinced that arts and culture are responsible for a nation's condition or society's mentality. But I don't accept this idea, I don't feel I am responsible for anything on such levels. [...] I simply don't feel like improving or influencing anyone, shaping or pushing in a certain direction. But I know it isn't possible in all respects for we always influence the others And this is maybe one of the reasons why I gave up making documentary films some time ago and now I give up making any films at all. [...] In a document this is the question of your responsibility for how much you influence the others. If you had a camera, especially in the old political days, you were peculiarly responsible for a man you directed your camera at. [] And besides -- everything I really think is a most important in a lifetime is much too private to make films about. It can't be filmed. And I escaped documentary films. [...]"(7)

In making feature films Kieślowski remained true to his documentary technique based on observing the Polish reality. He took as his reference an individual's life, a couple united emotionally or from a small group of 
colleagues working in the same factory or institution. Presenting fictional stories made it possible for him to concentrate upon his characters' psychological complexities, rooted not only in the world tainted with ideology but also in human nature itself. His characters were unsuccessful in their search of communication with others. They were condemned to fail as they were surrounded by a Kafkaesque or even Orwellian world. They lived in the socialistic Poland rightly called by Krzysztof Piesiewicz "the state of multiple sclerosis," while their attitude could be best described by the phrase: "Only I am right!"(8)

The drama of no solution was the subject of the first Kieślowski's television feature film, Pedestrian Subway (1973), based on the literary idea of Ireneusz Iredynski, a writer fascinated with immorality and the selfdestructive tendencies of man. The film not only presented the story of an unfortunate rebirth of the character's love, but also peripheral images and events, such as walls, a view from a window, a crumpled piece of paper in the wind.

A semi-documentary style dominated also in Personnel (1975), an inquiring and ironical image of theatre microcosm observed from the perspective of a former student of the Theatre Techniques College (from which Kieślowski also graduated). A young, enthusiastic tailor, a new employee, becomes involved in a conflict between the actors and the technical staff of the theatre which develops into a personal ordeal for him. The young man's character was performed by Juliusz Machulski (in the following years he too became a well known director). The scenes presenting opportunists, sycophants and pretenders were recorded using telephoto lens which gave the impression of the main character peeping at them through a door crack. The camera often stopped on the faces of characters who listened to statements of other theatre workers speaking off-frame. Thanks to the 'descriptive' narration style, the director managed to expose the characters' ridiculous attitudes, but at the same time he did not try to hide his liking for them.

There is no doubt that the world shown in The Staff was a metaphor of relations between the socialistic authorities and Polish society. The director's intention was understood by Polish and foreign film communities (Personnel was awarded the Grand Prix at the International Film Festival in Mannheim, 1975). The critics regarded the film to be the first example of the type of cinema later called by the young director Janusz Kijowski the "cinema of moral concern."

Kieślowski was also part of the "cinema of moral concern." That was the time when Andrzej Wajda's Człowiek z marmuru (Man of Marble, 1977) and Krzysztof Zanussi's Barwy ochronne (Camouflage, 1977) were regarded as the most exciting pictures expressing disapproval towards the communist regime, while Agnieszka Holland (Zdjęcia probne - Trial Shots), Feliks Falk (Wodzirej - Top Dog) and J. Kijowski (Indeks - Index) had just finished their first pictures. In Scar Kieślowski manifested his disagreement with radical solutions, he pointed out the ambiguity of various social and professional attitudes and analysed other aspects of the same phenomenon. Unlike his colleagues who were often referring to an intellectual character hesitating whether to become a conformist or to openly fight for personal freedom, Kieślowski in his made-for-TV Spokój (The Calm, 1976) again studied a worker dissatisfied with his existence. After leaving the prison, the character felt stigmatized. This induced him to fight for independence and personal dignity. Like the tailor from Personnel, he soon became a manipulated person; however, since there was no simple contrast of good and evil between the protagonist and his opponents, they could not be easily reconciled one with another. In Kieślowski's opinion solving a dilemma still is not a warranty of easy life.

A dilemma is not to be solved -- it is for us to live with. This is what Filip Mosz, the character of Amator (Camera Buff, 1979) is convinced of. The movie, one of the most important "pre-Solidarity" works, was also the director's personal expression of his opinions on the moral responsibility of the "man with the camera." A small employee bought an amateur film camera to film his little daughter. However, soon after having received an award for a picture made on the occasion of his company's anniversary, he devoted himself to cinema. He neglected his family duties, got into conflict with his employer but learned how to conscientiously observe everyday life. Finally he realized the falsity of the reality and its film reflection. In the last scene the character turned the camera off the world, started recording himself and telling his own story. Kieślowski's remarked on this episode: "One cannot tell about the world other than telling about himself."

In her monograph on the "cinema of moral concern," Maria Kornatowska wrote ${ }^{(9)}$ that it exposed the facade of the socialist culture which was based on lies, party opportunists and empty slogans. At the same time, it brought the technique of descriptive realism to its limits beyond which nothing more could be said. This 
statement was shared by Kieślowski, for whom this was one of the reasons to stay away from any artistic trend. He stressed the impossibility of exact representation of the world through film and doubted in cognitive abilities of man. This was illustrated by symbols appearing more and more frequently in his feature films. Nevertheless, his symbols were deeply rooted in reality. When analysing individual attitudes he displayed his uncertainty and tolerance towards subjective description of oneself and the world around. First of all, however, he presented to the viewers the concept that no one opinion could be the only idea on one's life.

K. Kieślowski: "[...] To live in accordance with a certain model? This is what the Catholic Church does. And it stands against its own business, making it weaker and weaker for people who don't wish to be controlled. I'm sure that each of us generally knows and sees his own way. $[\ldots]{ }^{\prime \prime}(10)$

Kieślowski's films became increasingly saturated with ephemeral metaphysical light and in this way they were able to express the complex truth on changes taking place in Polish consciousness and spiritual life in the early 1980s. In Przypadek (Blind Chance, 1981) the creator presented three versions of a young man's life. In the first one, the character was influenced by an old communist he met on a train and began his own political career going through several inner conflicts. The second variant of his existence also began at the railway station but this time Witek missed the departing train. For his scuffle with a railway guard he was sentenced to hard labour and there he met people from the underground political opposition. But this experience brought him sorrow and disappointment, too. In the third story the character missed the train but met a student girlfriend with whom he fell in love. He became a happy father while his professional career, devoid of political involvement, brought him much satisfaction. However, when he travelled abroad by plane, it exploded in mid-air.

In the above variants of lives controlled by chance, the director anchored the plot in social realities. Nevertheless, contrary to Polish enthusiasm for the "solidarity" idea, Kieślowski was concerned with fatalism. He called fatalism "one of the most dangerous pollutants of consciousness caused by the totalitarian system and recreating this system over and over again." ${ }^{(11)}$ And there is nothing surprising in the fact that both critics and viewers were not happy with this film which showed the world beyond human control. The audience wished to see a clear ideological position following the recent political events, while the artist wanted them to think about human existence as a combination of accidental events, various decisions made by the individual, ambiguity, and life's secrets.

Kieślowski did not change his point of view on film and reality even after political events had paralysed the social and cultural life in Poland. In the mid-1980s, when a number of ambitious filmmakers aware of social problems decided to stop making films, while others aggressively condemned opposing ideologies -he proclaimed the importance of secrecy to an individual and expressed it well in Bez konca (Without End, 1985). The plot of this film takes place in 1982, just at the beginning of the imposition of martial law. Here, the political discussion was raised to the psychological level and united with the personal drama of a young attorney's widow.

A day after the funeral ceremony, the dead man returned to reality and began affecting the existence of Dariusz, a young worker who had been charged by the military government with organizing a strike. Three lawyers suggested to him three different courses of defence: The first one was the dead man's spirit who encouraged Dariusz to stand firm by the values he believed in. The second suggested a compromise ("you should smile hypocritically and leave the prison"), while the third one advised to him express his hatred for the authorities. But Dariusz decided to follow his own opinion which suggested he was neither a coward nor a hero. The widow did not manage to penetrate this matter and failing to find a sense of meaning in her life, finally committed suicide. The last scene showed the couple reunited after death.

The film was neither accepted by the official nor by the underground critics. In Without End, Kieślowski decided to explore the symbolic aspect of the narration and juxtaposed an individual's fundamental principles and personal loyalties on one hand and the loyalty to the Polish nation and state on the other. Kieślowski wrote the screenplay together with Krzysztof Piesiewicz and that was the beginning of their almost ten-year long collaboration. Later they developed Dekalog (Decalogue, 1988-1989), a series of ten feature films based on the idea of the ten commandments. ${ }^{(12)}$ Decalogue brought its creators international fame while in Poland they were regarded as controversial artists since they did not "utter the name of God to misuse it." 
K. Kieślowski: "[...] I think if there is anybody like God who created everything around, and us, too, I think we often get out of His hand. When you glance at the history of the world, our history, it can be easily seen how often we get out of hand."(13)

It can be said that Kieślowski looked for God but found him inside of people. He treated the plots in Decalogue as 'court files' presenting two opposing attitudes toward life. He did not divide his characters into those redeemed and the ones condemned. He transcribed sacred texts his own way; his stories can hardly be united with the Catholic doctrine in which the human fate is a part of mysterious divine intention.

In Decalogue I ("You shall have no gods before me") an extreme rationalist, who was not able to predict unplanned events, sustained a calamity. The man was sure that by using a computer he could properly calculate the thickness of the lake's ice, but his son drowned there. In Decalogue II ("You shall not utter the name of your God in vain") a young woman artist decided to give birth to a child conceived with her lover after the doctor had lied to her that her husband's death was unavoidable. The character of Decalogue III ("Remember the Sabbath day and keep it holy"), the adulterous husband left his lover on a Christmas Eve as he realized the motive of his behaviour. The character of Decalogue IV ("Honour your father and your mother"), a female ex- student, learnt she had an adoptive father. She searched with him for truth on their mutual feelings and wishes. In Decalogue $V$ ("Thou shalt not kill") the director reminded the viewers that their attitude towards capital punishment is of crucial importance when they want to be a part of a civilized society.

Decalogue VI ("Thou shalt not commit adultery") was a story about the meeting of a shy teenager and a promiscuous young woman. The meeting changed their lives: The boy stopped believing in love while the girl realized its true value. Decalogue VII ("Thou shalt not steal") illustrated the rivalry between a mother and a grandmother over a child. Two female characters in Decalogue VIII ("Thou shalt not bear false witness against your neighbour"), an ethics professor and an elderly Jew, try to come to terms with the past (Nazi occupation) and explain the reasons why a Polish woman refused to help a Jewish child. Decalogue $I X$ ("Thou shalt not covet your neighbour's wife") reveals the drama of an impotent cardiologist's jealousy of his wife's affair with a young man. In Decalogue X: ("Thou shalt not covet your neighbour's house or anything that is his") the characters were brothers wishing to enlarge inherited assets. One of them decided to swap his kidney for an invaluable postage stamp to complete a set. However, their greed was mocked by fate since during the operation in a hospital their house was robbed.

Kieślowski rarely illustrated the commandments (as in parts 1 and 5); he usually outlined their interpretation (in part 3), but most often he modified their traditional meaning (as in part 2 and 8). He did not hide his cognitive skepticism. He considered the events of each episode from a different perspective. By creating a character who appeared in each episode (performed by the same actor in different roles, such as a man with a ladder, suitcases or a boat) and situating all episodes into the same location (modern apartment subdivision), the author established a unified concept of the series. Gianni Buttafava was right when he wrote: "[...] the wish to give the series formal unity was honestly preserved: There is no highest will determining the events, or maybe there is, but each of us should find it for himself according to his faith." (14)

The plots of Decalogue avoided religious postulates and attitudes and as such they were not appreciated by Poles who were usually given dogmatic truths in the shape of a sermon or homily. They seemed to share the opinion of the festival jury in Gdansk where the two theatrical versions were shown. However, Decalogue received praise with foreign critics and audiences. At the International Film Festival in Cannes, A Short Film About Killing received the Special Award of the Jury for its courage in asking the most important questions and seeking a moral signpost in the modern world. The members of European Film Academy honoured the author with their prestigious Felix.

Despite his fame Kieślowski used to stress in interviews that he was not an artist ("An artist is someone who knows") but rather a craftsman doing his job to share his doubts on life and art. (15) He surely could not convince many people about this, especially after the commercial success of La double vie de Véronique (1991), a film which fascinated almost everyone with its gentle form and a new way of presenting the metaphysical side of human nature.

Half of this film's action took place in Poland (and was spoken in Polish) and half in France. There lived two 
almost identical girls in the two countries, Véronique and Weronika, both musically gifted. Although they did not know about each other's lives, they felt there must exist someone very close to them. Weronika died during her first philharmonic performance. After her death, Véronique was told about her heart dysfunction and decided to give up her singing career. The former paid with death for her fascination with music, while the latter had to leave a musical career and unexpectedly found love. Kieślowski portrayed two different cultures and explored two characters whom he tried to confront and compare. The metaphysical ambience of the film was not created by the plot or repeated motifs (e.g. the church on a rock), but mainly by profoundly varying the visual dimensions of the narrative. The film's two characters observed the environment 'upside down' and watched the world through different prisms (e.g. through stained-glass windows, distorting windows, mirrors, glasses, glass spheres and lens).

However, Kieślowski did not much appreciate his own work. During preparations for the French-Polish-Swiss co-production entitled Trois couleurs: Blue, Blanc, Rouge (1993-1994), inspired by the colours of the French flag and symbolizing ideas of Liberty, Equality and Fraternity, he often spoke about his creative difficulties. He felt it less and less necessary to speak through film images.

K. Kieślowski: "[...] The film doesn't exist without a viewer. And the viewer is most important. The art for art's sake, form for form's sake, falling down under the weight of self talent or sagacity -- these aren't things for me. I want to tell a story which touches people, for touching is close to me. [...] I started making feature films -- I thought it was much easier as far as responsibility was concerned. What do I actually do? I hire actors, people for a certain job. And I have made those movies for many years, and suddenly I saw that I have left a normal life completely, in which something else is important, for the next day depends on it and the people's attitude towards us depends on it, too. I left this all and actually chose a very comfortable place where everything is imagined and lots of money is spent on a fabulous life or a world that doesn't exist. There are huge emotions in this world, but they are untrue. And I realized I went to a completely ridiculous place, I started living in a life that's untrue. [...] that I have no normal life at all... [...] There is no life. There's only fiction instead. [...]"(16)

In Kieślowski's opinion there is neither liberty nor equality in the world. Nevertheless, mankind should try to make those ideas unforgettable and he should even try to find a way towards them. That is why the films, inspired by the European thought that had risen from the Great French Revolution, reflected the reality full of axiologic confusion, where new values can be created only by means of individual attitudes. And this is the reason why the symbolism of colours in the title was filled with ambiguity: Blue was mixed with green, white with red, and red with gray. The blue became an equivalent of music and remembering the dead, the white was a representation of the world wanting deeper meaning, while the red was united with love and hate.

Julia, the character of Blue, after having lost her husband and daughter who died in a car crash, tried to forget anything related to the past, but freedom as a slogan became an existential trap and illusion. This way she chose 'freedom to', (probably to love) since the words of the hymn composed by her deceased husband referred to it. Karol, the character of White, was deceived by his French wife and decided to punish her through deception. He arranged his own death and after his wife had come to Poland to the funeral, the couple spent the night together and experienced renewed love. But can it be that the real love is built upon the right of both sides to get revenge? Valentine, the character of Red, accidentally met an old bitter recluse judge who spent his time tapping into the phone calls of his neighbours. She made him realize that a man can accept the people and the world around him rather than to escape them.

"A short film on telephones" -- as some critics called the last part of the trilogy in which characters often communicated by phones -- was often interpreted as Kieślowski's summary. Barely before its premiere the director stated he would not make any more films. In fact, he really incorporated this statement into his picture, as Maria Kornatowska noted: "Red is probably the most evolved and most interesting of Kieślowski's films. It is a movie on a movie, a reflection on creating, on the dialogue between the artist and product of his imagination. An ingenious documentary maker realized, along his artistic path, that the screen reality is an entirely arbitrary and subjective creation. It is a pure creation." ${ }^{(17)}$ At the same time, however, the director contrasted his own pessimism with the creed hidden inside the film plot: There is neither liberty 
nor equality, but there may exist fraternity since in everybody's life there may appear someone who opens his or her window that has been closed to the world. At Kieślowski's funeral, Prof. J. Tischner said of him:

He used light and shadow to explore the truth about man. [...] He explored from the darkness the substantial matter of our world -- the matter of humanity. While some artists presented the drama of Polish hope, and the others guarded the memory of Polish suffering or considered the question of power and bread -- Kieślowski went further and deeper and displayed a flaw inside the human being. A man flawed inside who faces an incredible task: How to be in harmony with himself. [...] the artist and expert of human secrets let the light into human flaws and suggested the possibilities of reconciliation. This way he mediated the meeting of man with himself. While other artists mediated the meeting of people with the world -- he mediated the man's meeting with himself. [...] he showed people that within their reach there exists a power by means of which they can achieve harmony with themselves. There is a Decalogue somewhere Someone sings a Love Hymn It is said that Poland did not understand Kieślowski. But what is Poland? Politicians did not understand him for he was not enough a politician. And doctrinaires did not understand him for he was not one of them at all. But is Poland, which does not understand, really Poland? [...]"(18)

This skillful filmmaker who ignored styles, fashions, forms, snobbishness and genres annoyed and fascinated many viewers. His movies always escaped schematic interpretation. Critics obstinately tried to point the tradition Kieślowski followed. He was identified with Andrzej Munk as both artists began their careers in documentary cinema, got engaged into political affairs of their country and then turned to inner, metaphysical cinema. ${ }^{(19)}$ The similarity to the social-political movies of Ken Loach and philosophical screen essays of Krzysztof Zanussi was also stressed. But these aspects were always hidden behind the independent and very personal character of Kieślowski's cinema. In the 1970s, the philosophical questions he used to ask were read as political, and in the ' 80 s and '90s -- as religious ones. Nevertheless, his movies could not be enclosed in such interpretations since there are no unequivocal answers within them. ${ }^{(20)}$ After all, he presented the world "lacking idea on itself." (21)

Kieślowski died unexpectedly in March, 1996, and critics tried to create a synthesis of his artistic output again. Nevertheless, they usually stated that Red was by the director's intention his last work in which he concentrated all the basic components of his thought, poetics and style. In that, it did not close Kieślowski's philosophical investigations. He was obstinately looking for truth and formulated more and more hypotheses on it. He did not wish to and could not stop thinking about it; he could only stop his stories about people, their lives and art.

(Translated by Andrzej Cimala)

\section{Notes}

1. See Syndrom konformizmu? Kinematografia polska lat sześćdziesiatych. (The Syndrome of Conformity? Polish Cinema in the Sixties). Ed. Tadeusz Miczka and A. Madej. Katowice: Wydawnictwo Uniwersytetu Śląskiego, 1994, passim.).

2. Fragments of the directors' statements from a documentary Krzysztof Kieślowski - I'm so-so, made by Krzysztof Wierzbicki in 1995 for Danish TV.

3. Ibid.

4. Maciej Parowski's words, in: Stanislaw Zawiśliński, Kieślowski bez końca (Kieślowski Without End). Warsaw: Wydawnictwo Skorpion, 1994, p. 77.

5. The official name of the Polish Communist party.

6. Fragments of the directors' statements from a documentary Krzysztof Kieślowski - I'm so-so, made by Krzysztof Wierzbicki in 1995 for Danish TV.

7. Fragments of the last interview with Krzysztof Kieślowski from March 9, 1996, four days before he died. 


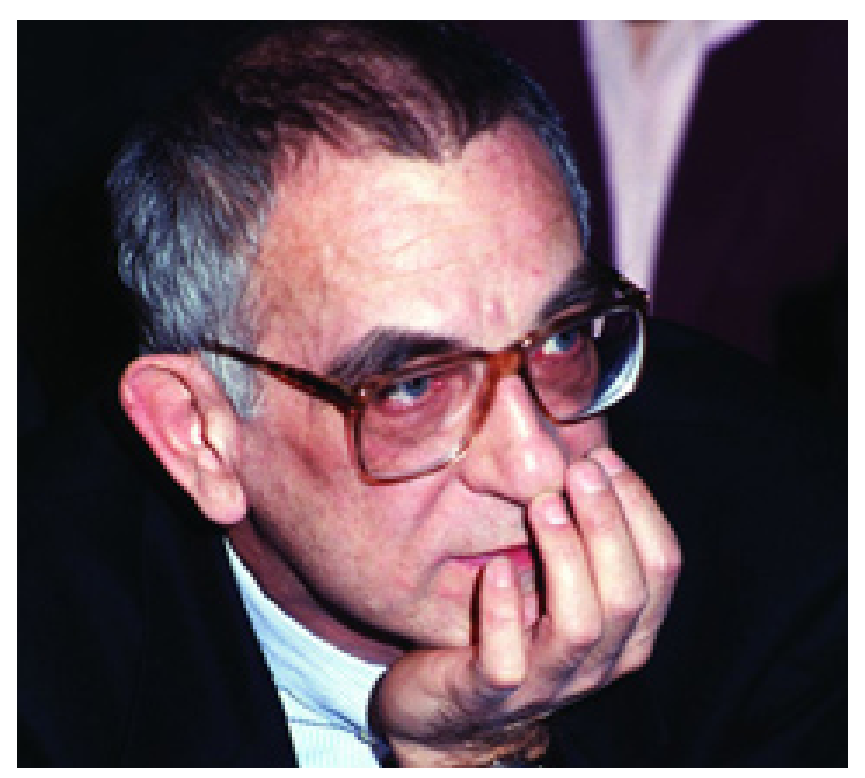

Figure 1: Krzysztof Kieślowski

Interviewers were students from a Katowice's gymnasium, the editors of the school magazine Incipit.

8. See Ponad podziałami (Above the Splits). An interview of T. Sobolewski with K. Piesiewicz. Kino 1994, No. 6,13$)$.

9. Maria Kornatowska, Wodzireje I amatorzy (Professionals and Amateurs), Warsaw 1990.

10. Fragments of the directors' statements from a documentary Krzysztof Kieślowski - I'm so-so, made by Krzysztof Wierzbicki in 1995 for Danish TV.

11. M. Jankun-Dopartowa, Czlowieczeństwo zawrócone. Trzy przypadki bohatera lat osiemdziesiatych. (Human Nature Turned Back. Three Cases of the 80s Hero.) In: Cztowiek z ekranu. Z antropologii postaci filmowej. (The Man From the Screen. About Anthropology of the Screen Character). Eds. M. JankunDopartowa and M. Przylipiak. Cracow: Arkana, 1996, p. 170).

12. Two episodes were produced in extended versions for theatrical distribution under the titles $A$ Short Film About Killing and A Short Film About Love.

13. Fragments of the last interview with Krzysztof Kieślowski from March 9, 1996, four days before he died. Interviewers were students from a Katowice's gymnasium, the editors of the school magazine Incipit.

14. G. Buttafava, "Fai, che cosa puoi." In: Ed. di M. Furdal and R. Turigliatto, Cinema di Kieślowski, Torino: Museo Cinematografico, 1989.

15. Kieślowski on Kieślowski. London-Boston 1993.

16. Fragments of the last interview with Krzysztof Kieślowski from March 9, 1996, four days before he died. Interviewers were students from a Katowice's gymnasium, the editors of the school magazine Incipit.

17. M. Kornatowska, Kreacja w czerwieni (Creation in Red). Kino 1994, No. 7-8, p.29.

18. Fragments of homily given by rev. Prof. Józef Tischner in March 20, 1996, during the funeral ceremony.

19. M. Przylipiak, Kieślowski - kontynuator Munka (Kieślowski - Munk's Follower). Kino 994, No. 6, p. $14-15$.

20. T. Sobolewski, "Peace and Rebellion. Some Remarks on the Creative Output of Krzysztof Kieślowski." In E. Nurczyńska-Fidelska \& Z. Batko ed.: Polish Cinema in Ten Takes. Łódz: Łódzkie Towarzystwo Naukowe, 
1995, pp. 123-138.

21. Krzysztof Kieślowski, quote from a book by Stanislaw Zawiśliński, Kieślowski bez końca (Kieślowski Without End). Warsaw: Wydawnictwo Skorpion, 1994, p. 31.

\section{References}

\section{Krzysztof Kieślowski's Films}

\section{School films}

1966 - Tramwaj (The Tram - feature film), Urzad (The Office - documentary film);

1967 - Koncert życzen (Concert of Request - documentary film);

1968 - Zdjeccie (The Photograph - for TV);

1969 - Z miasta Lodzi (From the City of Lodz - a diploma film).

\section{Documentary films}

1970 - Bylem żolnierzem (I was a Soldier), Fabryka (Factory);

1971 - Przed rajdem (Before the Rally);

1972 - Robotnicy '71: Nic o nas bez nas (Workers 71.: Nothing about us without us - together with Tomasz Zygadło, Wojciech Wiszniewski, Paweł Kędzierski and Tadeusz Walendowski), Refren (Refrain), Między Wroctawiem a Zielona Gora (Between Wroclaw and Zielona Gora), Podstawy BHP w kopalni miedzi (The Principles of Safety and Hygiene in a Copper Mine);

1973 - Murarz (Bricklayer);

1974 - Prześwietlenie (X-ray), Pierwsza miłość (First Love);

1975 - Życiorys (Curriculum vitae);

1976 - Klaps (Slate), Szpital (Hospital), Krótki dzień pracy (A Short Workday - feature document for TV);

1977 - Nie wiem (I don't know); Z punktu widzenia nocnego portiera (From a Night Porter's point of view);

1978 - Siedem kobiet w różnym wieku (Seven Women of Different Ages);

1980 - Dworzec (Station), Gadające glowy (Talking Heads);

1988 - Siedem dni w tygodniu (Seven Days a Week).

\section{Feature films}

1973 - Przejście podziemne (The Underpass - for TV);

1975 - Personel (The Staff - for TV);

1976 - Blizna (Scar), Spokoj (Calm - for TV);

1979 - Amator (Camera Buff);

1981 - Przypadek (Blind Chance);

1985 - Bez końca (Without End);

1988 - Krótki film o zabijaniu (A Short Film About Killing), Krótki film o milosci (A Short Film About Love);

1989 - Dekalog (Decalogue - 10-part series, Polish-West Berlin co- production);

1991 - La double vie de Véronique (Double Life of Veronique - French-Polish co-production);

1993/94 - Trois couleurs: Blue, Blanc, Rouge (3 parts series, French-Polish co- production). 


\section{Author Information}

Tadeusz MICZKA is Director of the Institute of Cultural Studies, Faculty of Philology, University of Silesia, Katowice, Poland. His main fields of research are history of the Polish, Italian, and Central and East European cinemas, film theory, and issues related to modern media, including neo-television, virtual reality,

audio-visual communication. Prof. Miczka is the author of many publications on the history and theory of cinema, methodology of education and of comparative researches on contemporary culture. 